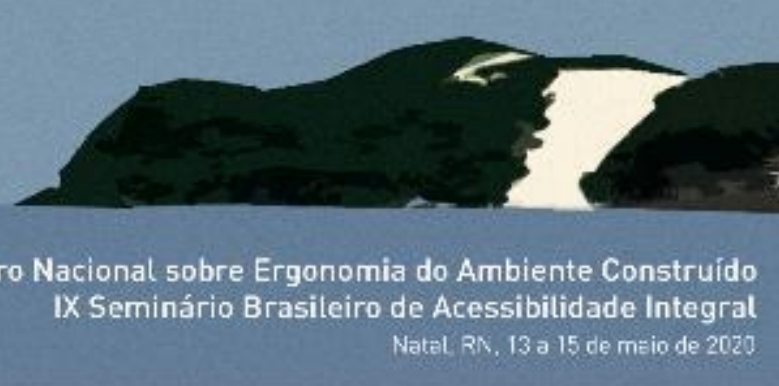

\title{
Da teoria à prática: o desafio real do Terminal Rodoviário de Salto/SP.
}

\author{
From theory to practice: the real challenge of Salto Bus Terminal.
}

\author{
MARIANA BERTANI BAPTISTA LOPES \\ Arquiteta e Urbanista, Mestra em Arquitetura, Tecnologia e Cidade - UNICAMP, \\ Professora do Centro Universitário Nossa Senhora do Patrocínio, \\ e-mail: marianabaptista.arquiteta@gmail.com
}

\begin{abstract}
RESUMO
Este trabalho pretende apresentar, de forma sucinta, o desafio aceito por uma entidade de acolhimento de idosos em caráter de longa permanência, o Lar Frederico Ozanam - Assistência Vicentina, em administrar como concessionária o Terminal Rodoviário da Estancia Turística de Salto, interior de São Paulo, onde, dentre outras atividades, deve prover acessibilidade com o objetivo inicial de adequar-se à Lei Federal 10.098/2000. Tendo em vista a necessidade desta adequação e sabendo da importância constitucional do direito de ir e vir e da possibilidade de transformar o Terminal com as premissas do Desenho Universal, foi colocado o desafio de elevar este equipamento público num modelo de acessibilidade para o interior do estado. As mudanças vêm sendo incorporadas desde 2017 de acordo com grau de importância, levando em consideração desde a inserção urbana do Terminal até os aspectos financeiros da entidade administradora. Atualmente as necessidades primordiais já foram atendidas, e estamos na fase de renovação da pavimentação. Posteriormente serão feitos a sinalização, novos acessos em rampa e instalação de mapa tátil interno e do entorno, com previsão de termino no final de 2021.
\end{abstract}

PALAVRAS-CHAVE: acessibilidade, intervenção, reforma arquitetônica, Terminal Rodoviário, Salto.

\section{ABSTRACT}

This work aims to present, in a succinct way, the challenge accepted by a long-term care institution for the elderly, Lar Frederico Ozanam - Assistência Vicentina, in managing as the concessionaire of the Bus Terminal of the Touristic City of Salto, in the interior of São Paulo, where, among other activities, it must provide accessibility with the initial objective of adapting to Federal Law 10.098/2000. In view of the need for this adaptation and knowing the constitutional importance of the right to come and go and the possibility of transforming the Terminal with the premises of Universal Design, the challenge was raised to elevate this public equipment into an accessibility model for the interior of the state. The changes have been incorporated since 2017 according to their degree of importance, taking into account from the urban insertion of the Terminal to the financial aspects of the managing entity. Currently the primary needs have already been met, and we are in the phase of renovating the paving. 


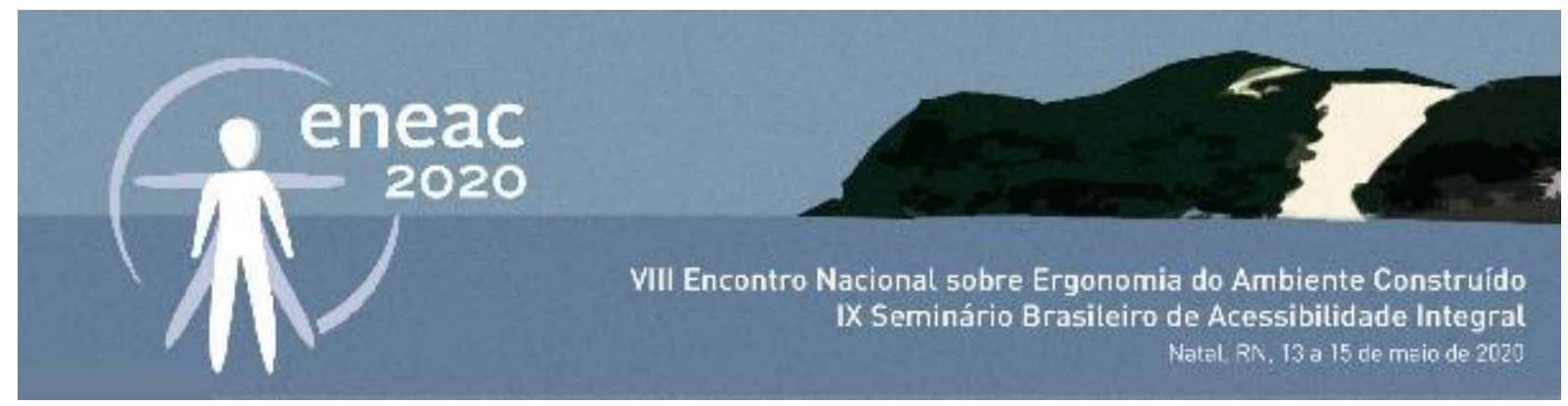

Afterwards, signage, new ramp accesses and the installation of an internal and surrounding tactile map will be carried out, with a forecast for completion at the end of 2021.

KEYWORDS: accessibility, intervention, architectural renovation, Bus Terminal, Salto.

\section{INTRODUÇÃO}

Salto é uma cidade do interior de São Paulo, localizada a $105 \mathrm{~km}$ da capital e pertencente à região metropolitana de Sorocaba. Nos seus atuais 320 anos de fundação, possui uma população de 120 mil habitantes, num território de $135.000 \mathrm{~km}^{2}$, e mesmo sendo a menor das cidades na região, Salto está localizada num ponto estratégico entre relevantes cidades do estado, como Jundiaí e Campinas, sendo cortada pela Rodovia Santos Dumont, principal via de escoamento de produtos, e estando a poucos quilômetros de distância do Aeroporto de Viracopos.

A cidade foi elevada à Estancia Turística pela Lei Estadual 10.360 de 02 de setembro de 1999, um ano após receber a primeira faculdade através do Centro Universitário Nossa Senhora do Patrocínio (Ceunsp). Atualmente, os cursos, tanto da Ceunsp, como do Instituto Federal de Educação, Ciência e Tecnologia de São Paulo (IFSP), atraem estudantes de cinquenta cidades da região. A presença de grandes empresas multinacionais, alemãs, japonesas e chinesas, colocam a cidade cada vez mais na rota do turismo de negócios.

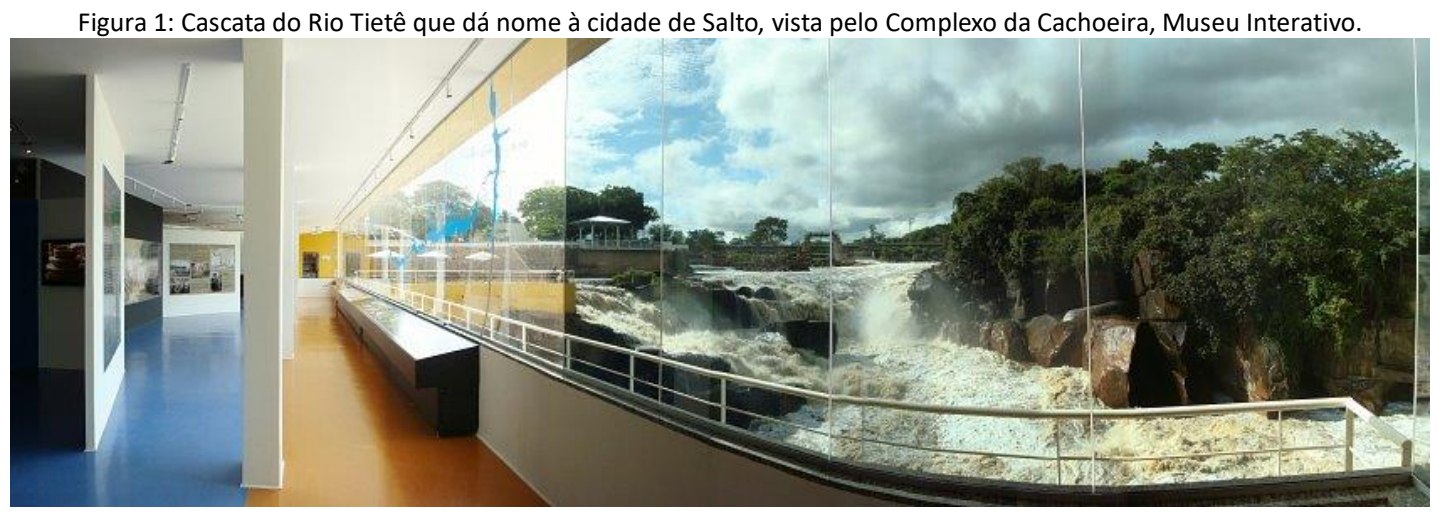

Fonte: Arquiteto Arlei Bertani, 2011.

O município também é reconhecido no estado pelo trabalho da Assistência Social prestada em diversos segmentos. A Sociedade de São Vicente de Paulo - SSVP, fundada no município em 1917, teve e tem como missão prestar o serviço de acolhimento permanente de qualidade a idosos em situação de vulnerabilidade social e pessoal. Na década de 50, a SSVP recebeu um lote em doação, onde já se encontrava uma edificação erguida, que foi reformada pelos próprios vicentinos e transformado no abrigo de idosos municipal, contando com uma ala feminina, uma ala masculina, capela, cozinha, sala de lazer e banheiros. Em 1998 foi projetado um novo edifício para acolhimento, finalizado em 2002, onde mais idosos podem ser atendidos. A SSVP mantém o serviço em funcionamento com auxílios federais, estaduais e municipais, donativos, administração de propriedades doadas e com a administração concessionária do Terminal Rodoviário municipal. 


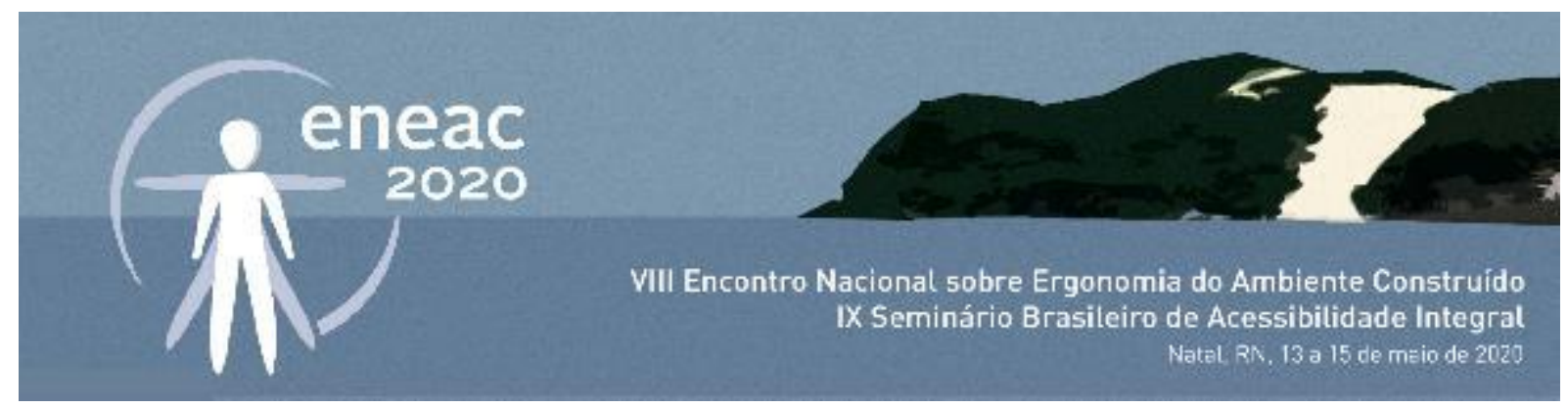

Através da Lei Municipal 3.695 de 2017, a SSVP - Salto renovou seu contrato de concessionária para administrar o Terminal Rodoviário da cidade por mais dez anos, se responsabilizando pelas benfeitorias no local e por atender as demandas da população usuária e locatários (Boxes de lojas e agencias de transporte), em contrapartida utilizando o lucro para suprir as necessidades dos idosos abrigados.

Figura 2: Fachada da Rua Marquês de Tamandaré, do Lar Frederico Ozanam, ala masculina à esquerda e ala feminina à direita.

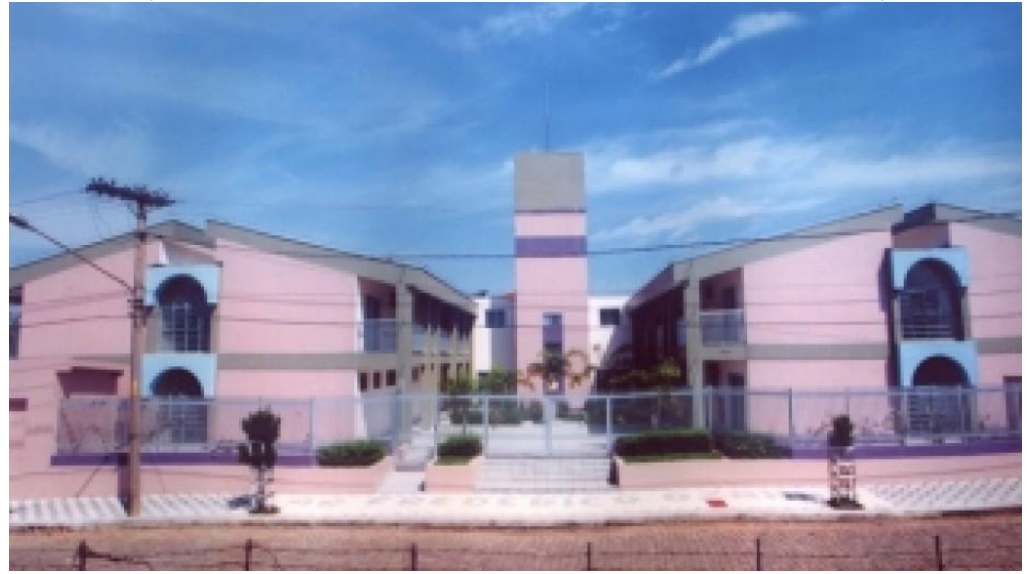

Fonte: Selo Social, 2016. (http://www.selosocial.com/projeto/789)

Inaugurado em 1988, o Terminal Rodoviário veio para suprir a falta de um local adequado para embarque, desembarque e permanência de passageiros, antes disso os ônibus utilizavam as ruas do centro da cidade para embarcar e desembarcar, expondo passageiros e pedestres ao risco de acidentes. O projeto contemplava uma área central aberta com grandes bancos de espera, à sua frente ficavam os taxis e atrás as plataformas dos ônibus. No lado esquerdo um bloco concentrava os guichês das viações e um segundo bloco os sanitários, até então divididos em masculino e feminino. Do lado direito outros dois blocos com boxes comerciais, sendo um deles, uma lanchonete. Até então não haviam leis que obrigassem os locais públicos a serem acessíveis, então o Terminal nasceu sem rampas e sanitários PNE. Somente em meados dos anos 2000 que houve a execução de 6 rampas de calçada permitindo o acesso de cadeirantes.

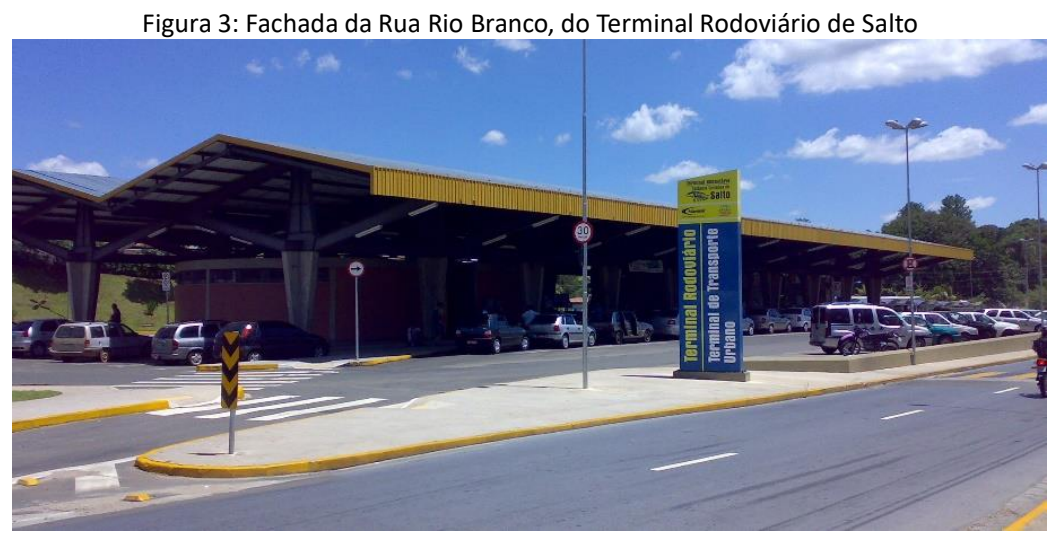

Fonte: Divulgação da Prefeitura, 2017. 

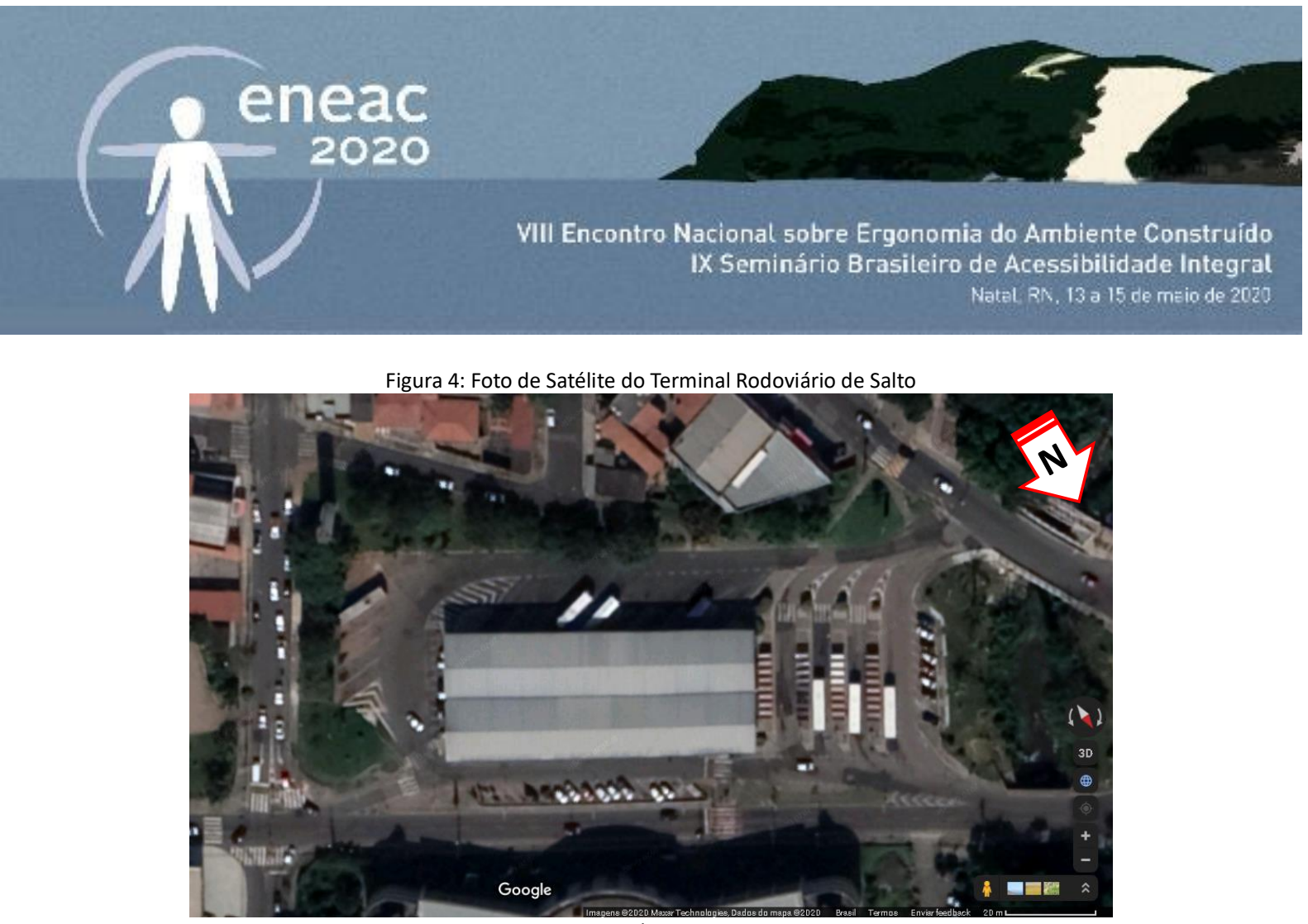

Fonte: Google Maps, 2020

Figura 5: Implantação do Terminal Rodoviário de Salto

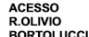

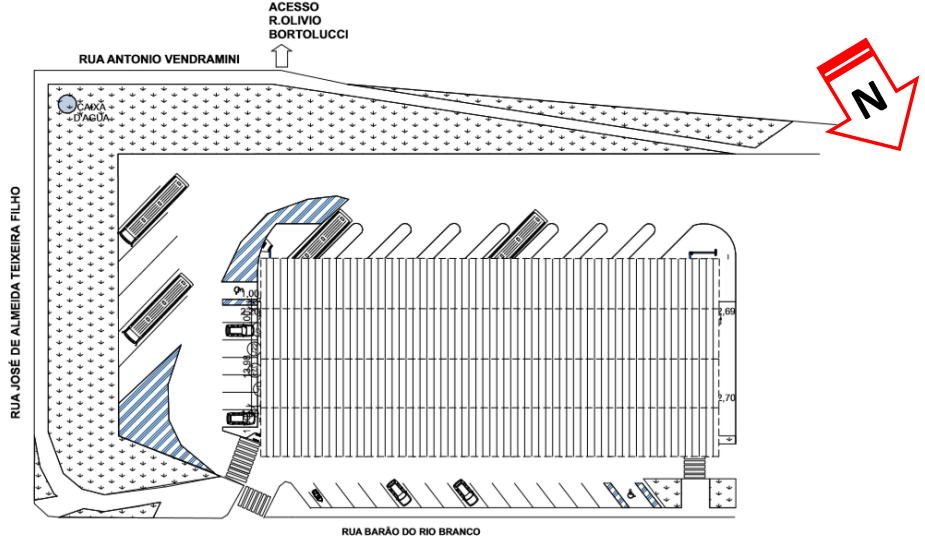

Fonte: Projeto Técnico, Arquiteta Mariana Bertani Baptista Lopes, 2017.

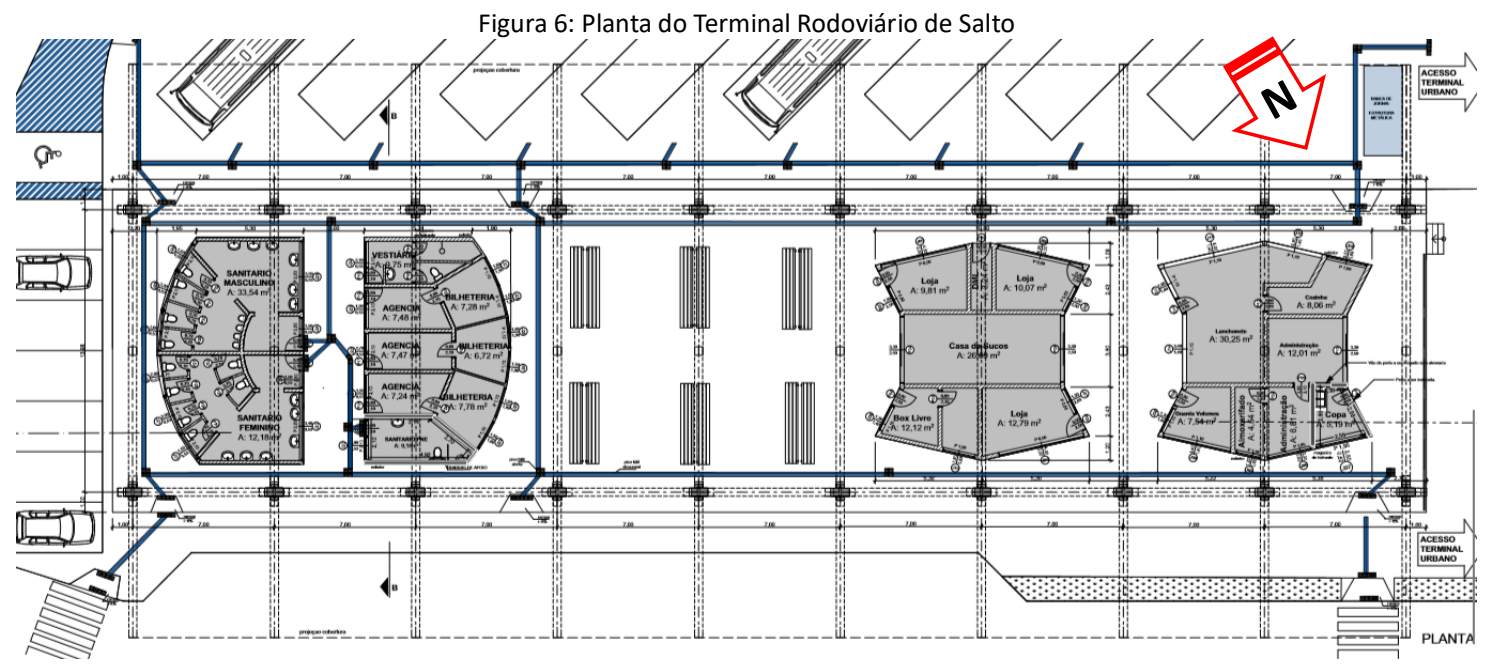

Fonte: Projeto Técnico, Arquiteta Mariana Bertani Baptista Lopes, 2017. 


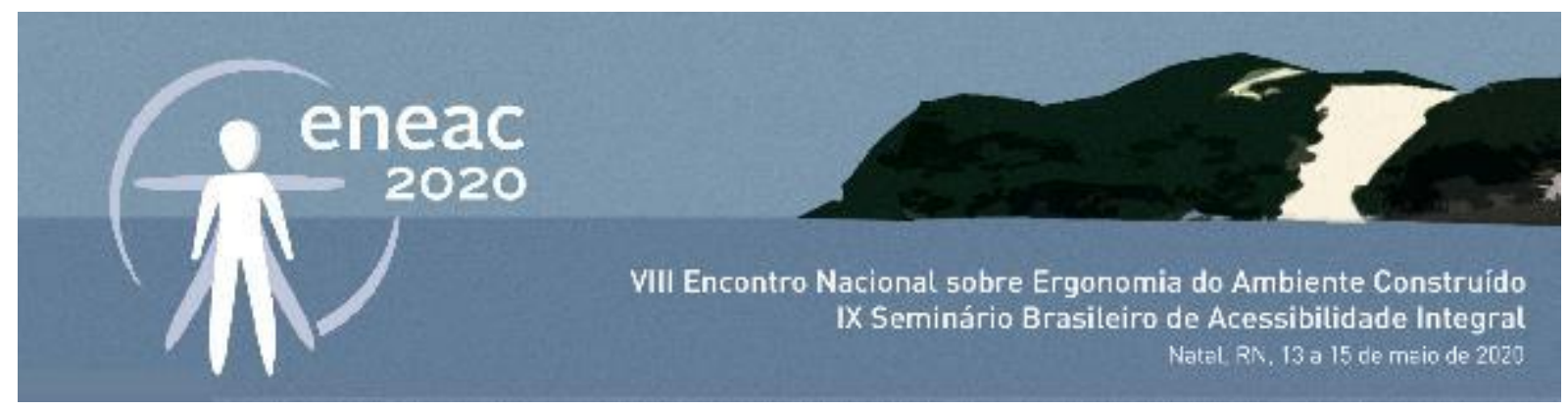

Na Lei Federal no10.098, atual redação de dezembro de 2000, foram estabelecidas as 'normas gerais e critérios básicos para promoção da acessibilidade das pessoas portadoras de deficiência ou com mobilidade reduzida, mediante a supressão de barreiras e de obstáculos nas vias e espaços públicos, no mobiliário urbano, na construção e reforma de edifícios e nos meios de transporte e de comunicação. (Art. 1으, Lei 10.098/2000). É possível associar seu texto ao discurso do Free Barrier Desing encabeçado pelo Americans with Disabilities Act (ADA), dos anos 50, pois ambos têm como preocupação garantir o direito de locomoção das pessoas com deficiência como uma necessidade básica, porém, apenas a lei brasileira define quem são as pessoas de interesse da lei:

\begin{abstract}
II - pessoa com deficiência: aquela que tem impedimento de longo prazo de natureza física, mental, intelectual ou sensorial, o qual, em interação com uma ou mais barreiras, pode obstruir sua participação plena e efetiva na sociedade em igualdade de condições com as demais pessoas; (Redação dada pela Lei № 13.146, de 2015)

IV - pessoa com mobilidade reduzida: aquela que tenha, por qualquer motivo, dificuldade de movimentação, permanente ou temporária, gerando redução efetiva da mobilidade, da flexibilidade, da coordenação motora ou da percepção, incluindo idoso, gestante, lactante, pessoa com criança de colo e obeso; (Redação dada pela Lei no 13.146, de 2015)

$\mathrm{V}$ - acompanhante: aquele que acompanha a pessoa com deficiência, podendo ou não desempenhar as funções de atendente pessoal; (Redação dada pela Lei no 13.146, de 2015)
\end{abstract}

A Constituição da República Federativa do Brasil de 1988, em seu artigo 5o, item XV, garante a livre locomoção no território nacional em tempo de paz, podendo qualquer pessoa, nos termos da lei, nele entrar, permanecer, ou dele sair com seus bens. A partir deste texto, a acessibilidade a logradouros públicos se torna direito dos habitantes e dever do Estado. Tal concretização do direito de ir e vir é fundamental para as pessoas com deficiência, pois as habilitam a usufruir dos demais direitos universais: Trabalho, Lazer, Estudo, etc. (FEIJÓ, 2002).

O projeto de reforma de acessibilidade do Terminal Rodoviário iniciou em 2017, com a necessidade de incluir um sanitário acessível, pois o Ministério Público já havia notificado o município para a realizar a adequação à Lei no10.098/2000 e à Norma NBR 9050/2004. Então, ao assumir a concessão do Terminal por mais dez anos, a Assistência Vicentina se comprometeu a fazer as adequações necessárias, e com auxílio de especialistas, arquitetos e engenheiros - grande parte trabalhando voluntariamente, decidiu transformar o Terminal num modelo de acessibilidade para as cidades do Estado de São Paulo.

Iniciamos a execução pelos itens de maior urgência: Sanitário PNE e identificação das plataformas. Em seguida foram atualizadas as partes elétricas e documentais, e como produto final haverá a substituição do piso, sinalização tátil, inclusão de rota acessível interna e externa ao Terminal, valorizando o cidadão com deficiência e convidando-o a conhecer e participar da cidade.

\title{
2 OBJETIVO
}

O objetivo deste artigo é trazer aos acadêmicos da área o relato da experiencia da autora como arquiteta na área de acessibilidade integral, seus frutos positivos e as muitas barreiras encontradas, 


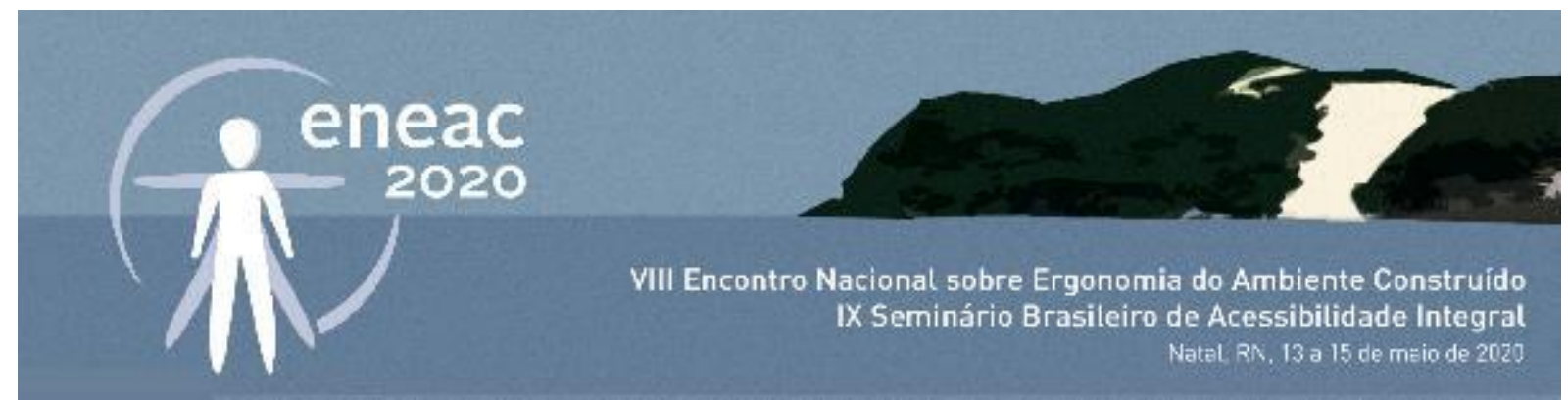

trabalhando em conjunto com uma entidade assistencial e necessitando prestar contas ao poder público.

Pretende-se também abordar como a acessibilidade é vista por leigos, e como essa visão, tão diferente da academia, pode confundir ou até mesmo impossibilitar a adequação dos espaços públicos.

\section{JUSTIFICATIVA}

A justificativa deste artigo possui duas direções:

- Primeira: expor no âmbito acadêmico a necessidade de interagir com o público leigo e estabelecer um diálogo proveitoso;

- Segunda: apresentar aos cidadãos como a acessibilidade integral é capaz de desenvolver as habilidades e a autonomia das pessoas com deficiência.

\section{METODOLOGIA}

A metodologia de projeto utilizada foi bastante simples, e podemos dividi-la nas três etapas a seguir:

1. Etapa de levantamento de dados: medições e avaliações in loco da estrutura e instalações;

2. Etapa de estudo de leis e normas: identificação dos itens a serem atendidos e sua importância dentro do cronograma de obras;

3. Etapa de projeto: desenvolvimento do projeto e aprovação em prefeitura.

E finalmente, após o projeto, a execução da obra também obedeceu a uma divisão em etapas, principalmente para não influenciar negativamente na utilização do Terminal e não prejudicar o fluxo de caixa da Assistência. As etapas foram as seguintes:

1. Etapa 1 - grau urgente: execução do Sanitário PNE e instalação de sinalização das plataformas;

2. Etapa 2 - grau improrrogável: atualização da rede elétrica e de documentos;

3. Etapa 3-grau fundamental: revitalização do piso e instalação de sinalização tátil;

4. Etapa 4-finalização: revitalização visual e instalação de mapas táteis e totens de informação.

\section{RESULTADOS}

Os resultados serão apresentados como antes e depois de cada etapa de execução.

\subsection{Resultados da etapa 1 - grau urgente:}

A execução do sanitário PNE utilizou o espaço de um dos vestiários de funcionários, a obra iniciou em novembro de 2017 e durou 15 dias, entrando em funcionamento no dia 1ㅇ de dezembro de 2017. 


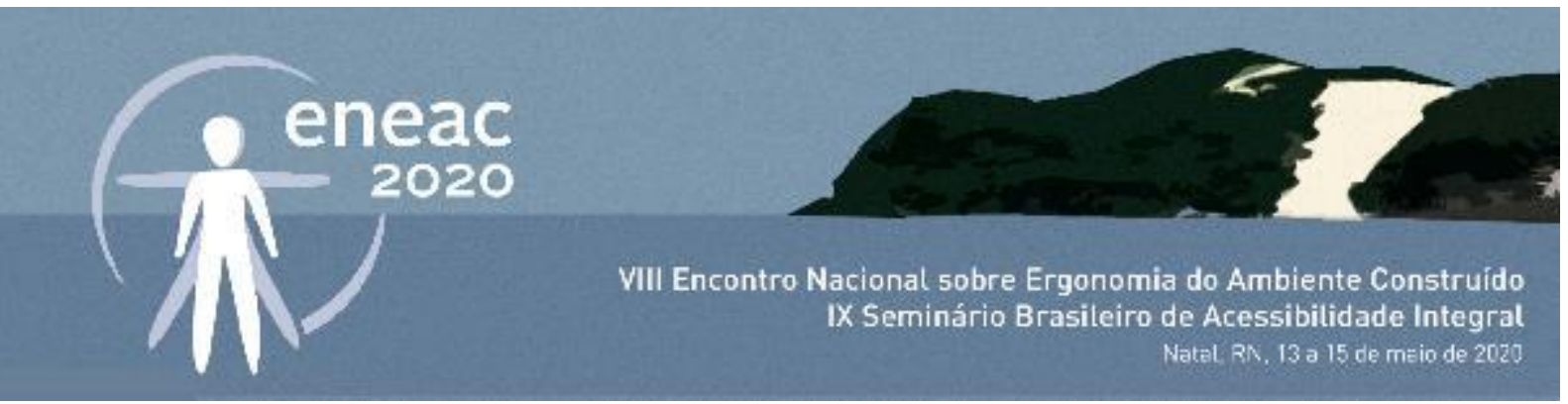

Figura 7: Planta de estudo de Sanitários PNE do Terminal Rodoviário de Salto - Vermelho: a reformar, Azul: existente. Projeto não chegou a passar por aprovação municipal.

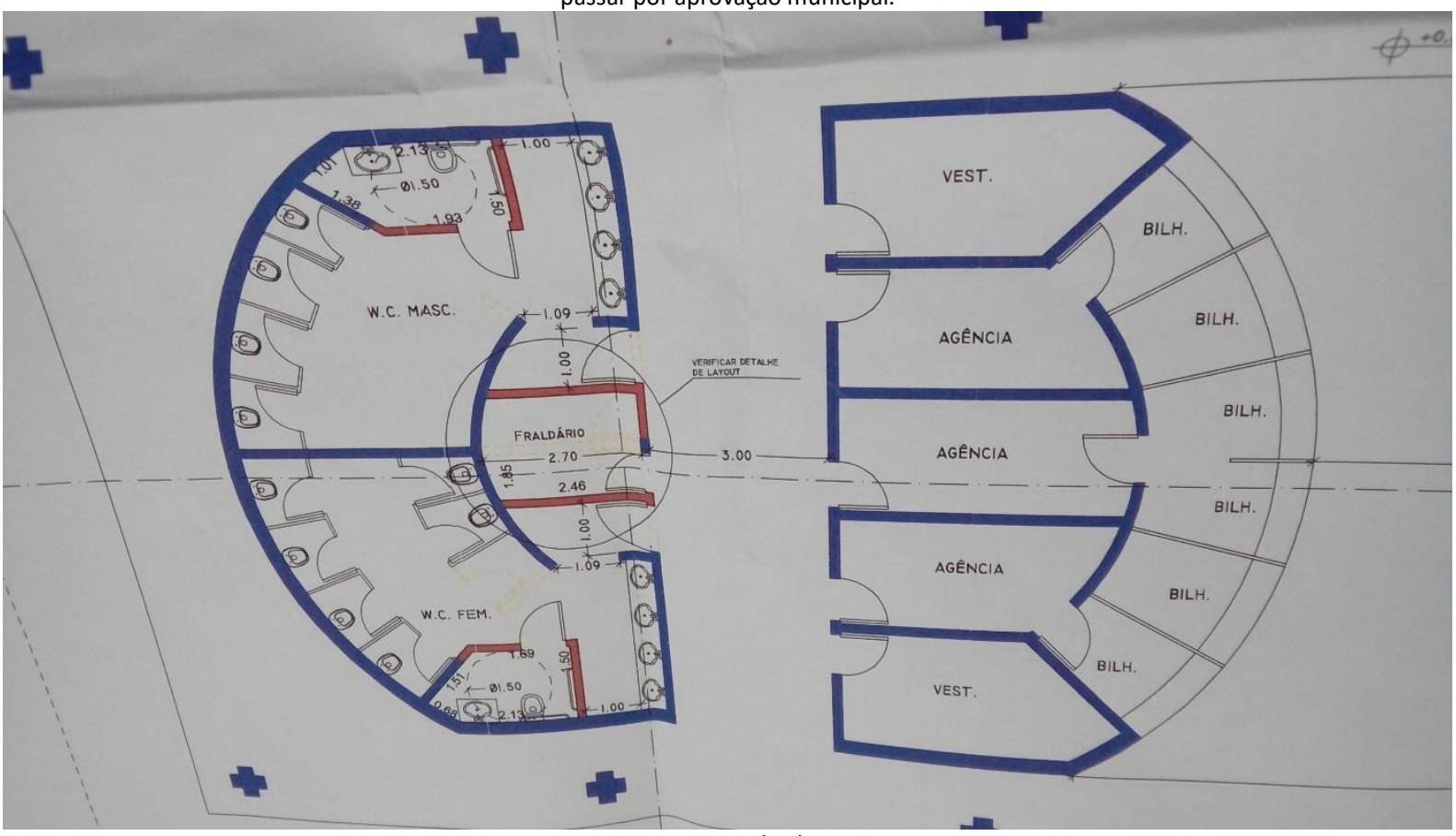

Fonte: Projeto Técnico, Arquiteto Nivaldo Panossian, 14/10/2015. - arquivo da administração do Terminal.

Figura 8: Planta de estudo de Sanitários PNE do Terminal Rodoviário de Salto. Descartada por não permitir passagem adequada e influenciar negativamente na volumetria do edifício.

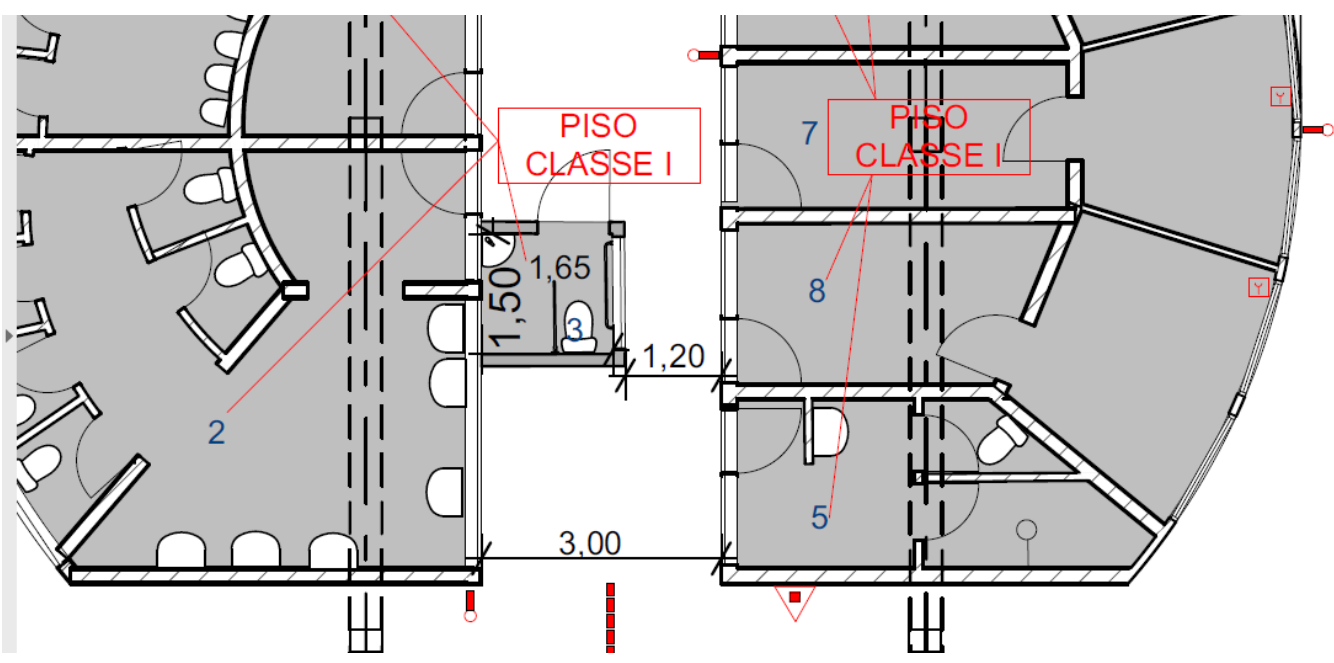

ו'ו'

Fonte: Arquiteta Arquiteta Mariana Bertani Baptista Lopes - arquivo professional da arquiteta. 

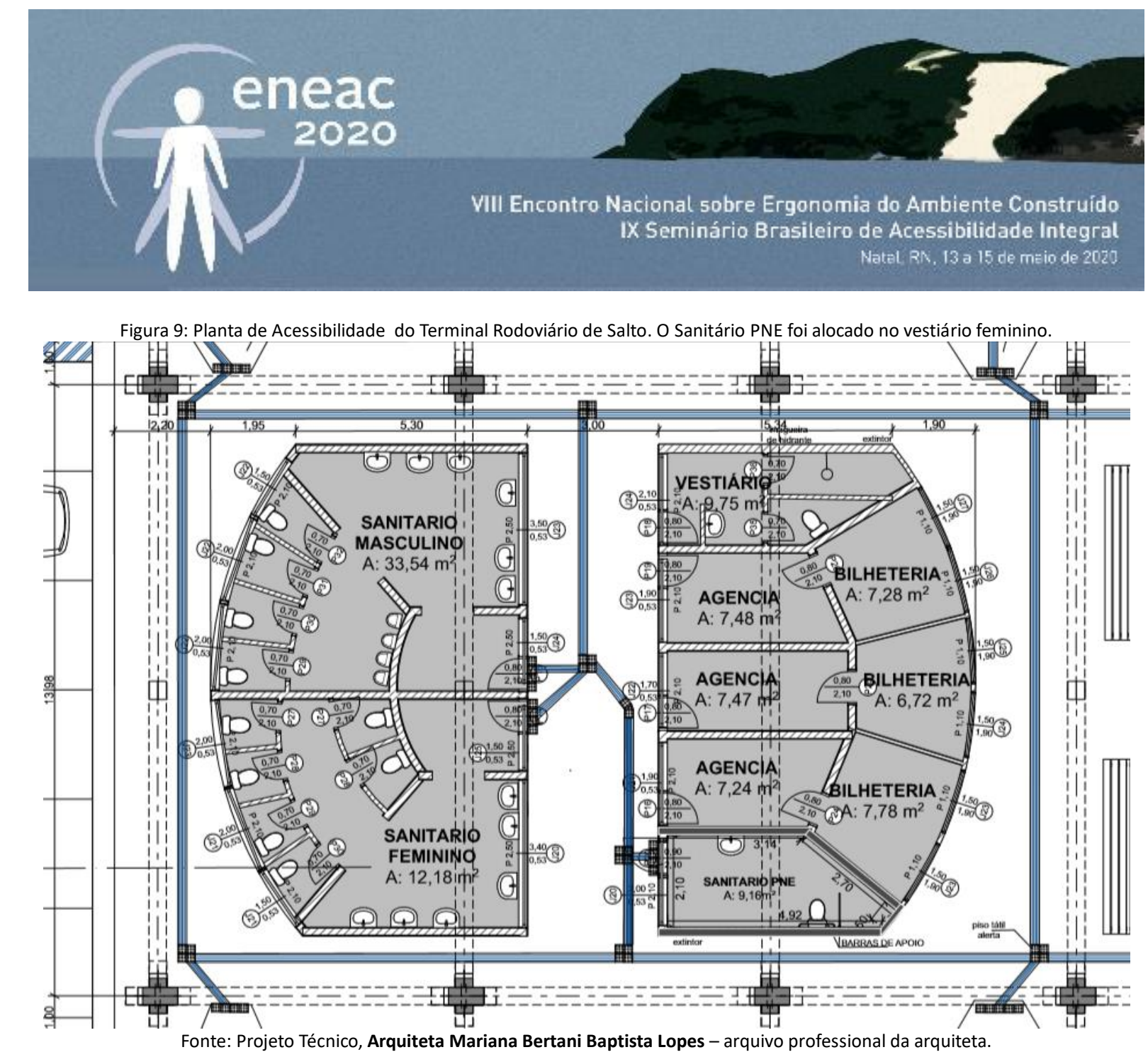

Figura 10: Planta de Acessibilidade do Terminal Rodoviário de Salto. O Sanitário PNE foi alocado no vestiário feminino.

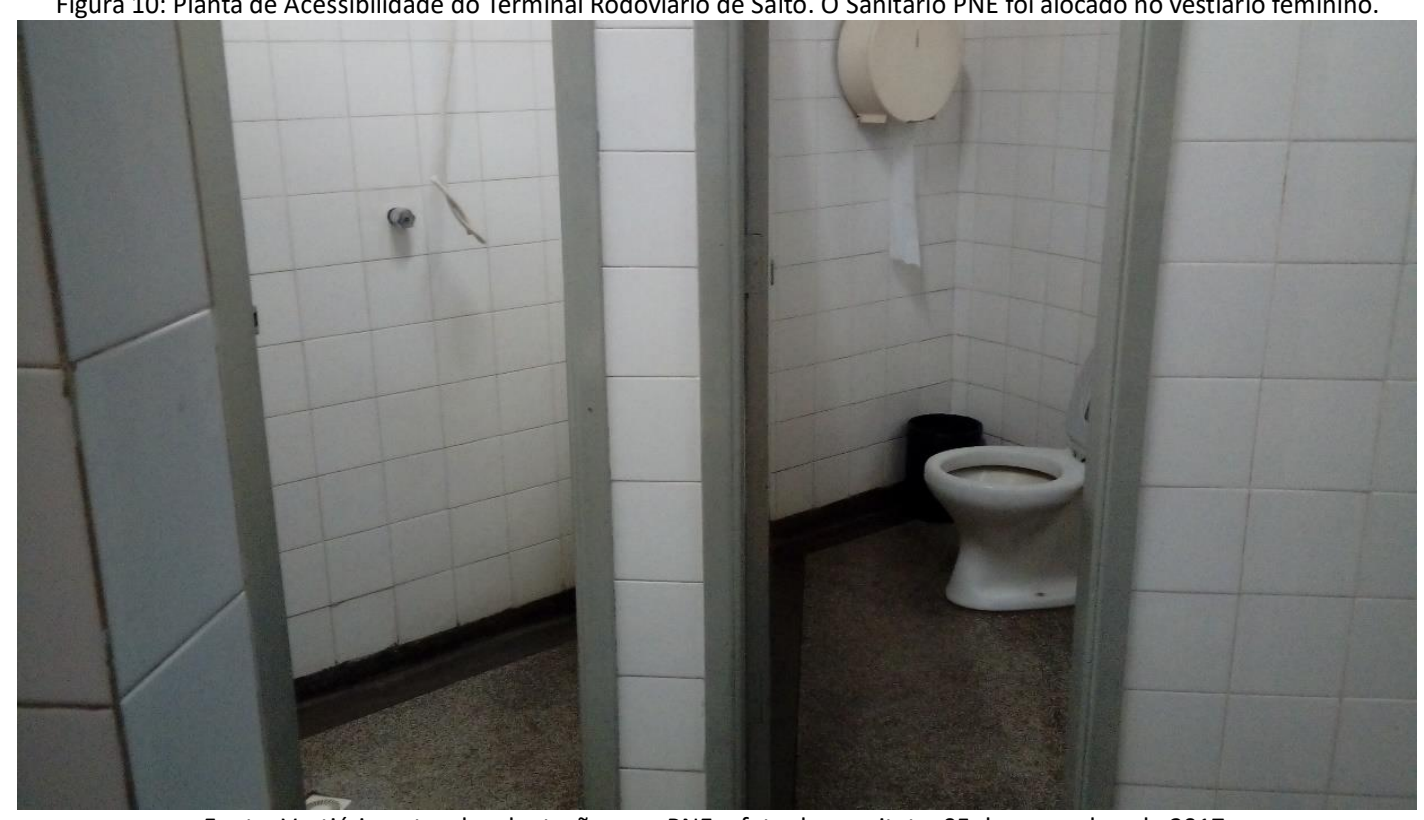

Fonte: Vestiário antes da adaptação para PNE - foto da arquiteta, 05 de novembro de 2017. 


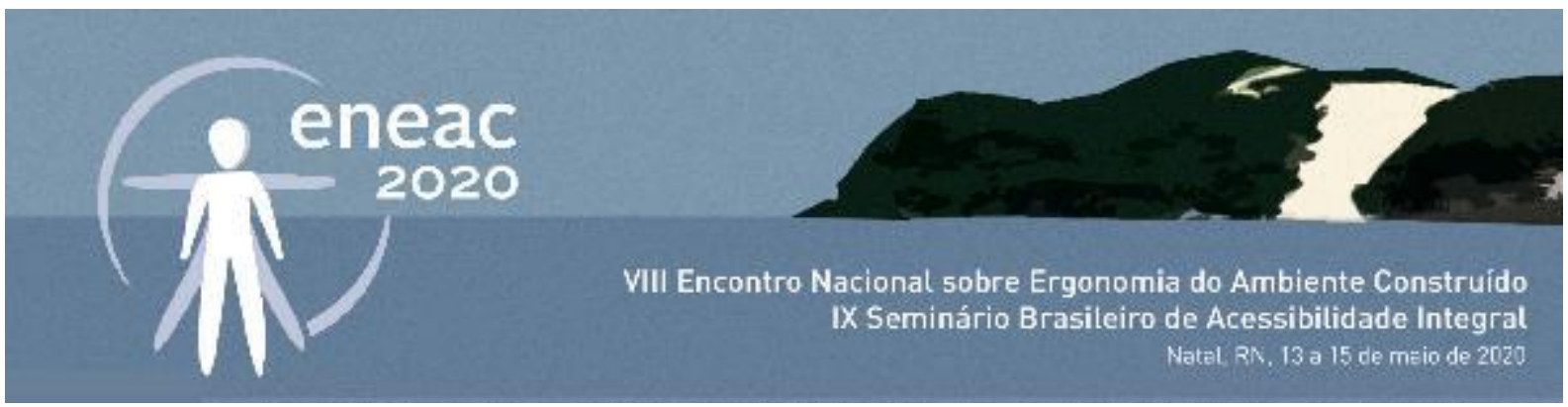

Figuras 11 a 15: Imagens do Sanitário PNE finalizado e pronto para uso (OBS: após este registro a papeleira foi deslocada 20cm para ficar na
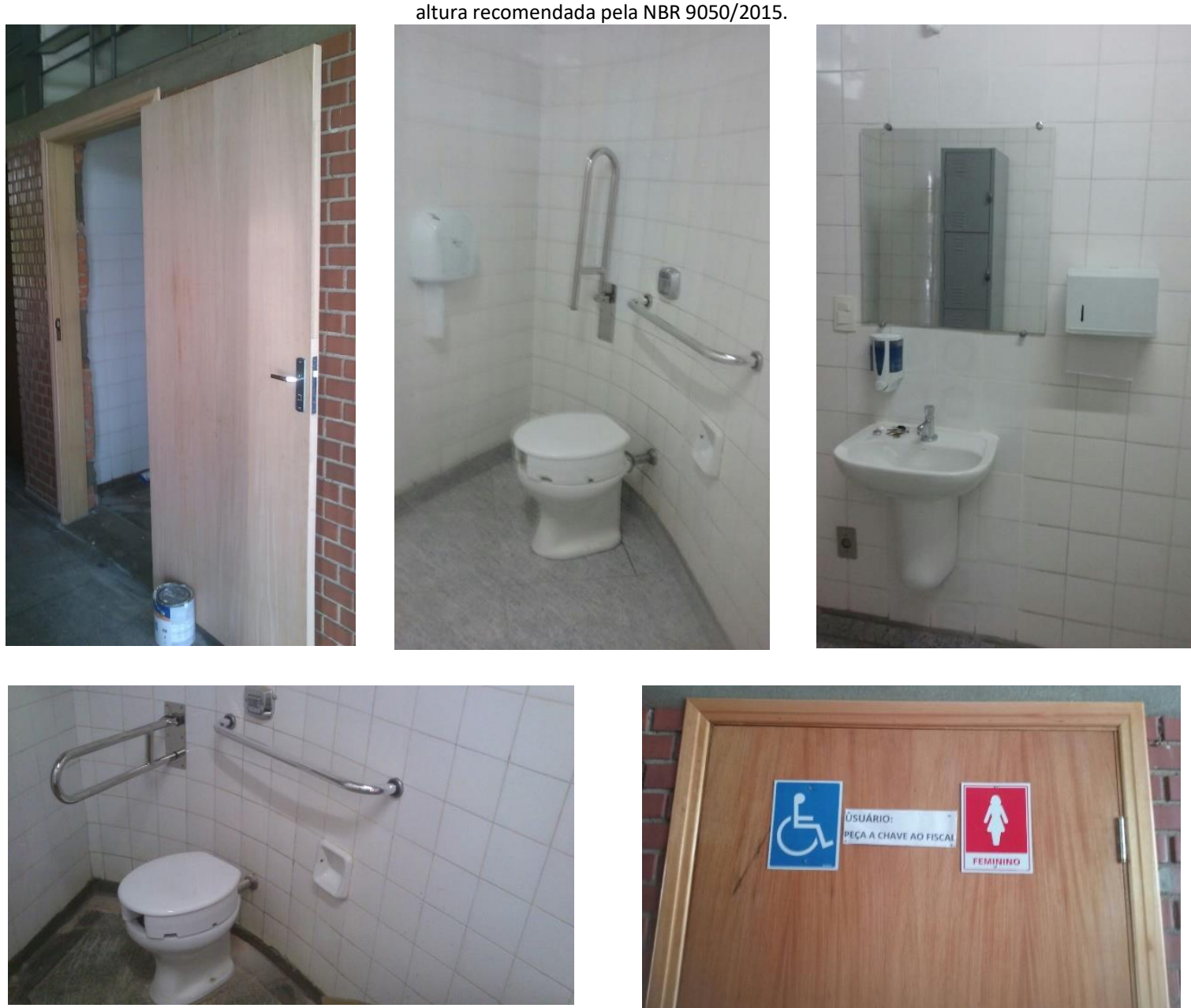

Fonte: foto da arquiteta, 20 de novembro de 2017.

As identificações das plataformas foram realizadas na mesma época, e entre criação do padrão visual, manufatura dos totens, instalação e adesivação, o trabalho foi totalmente finalizado e entregue à população no dia 17 de dezembro de 2017.

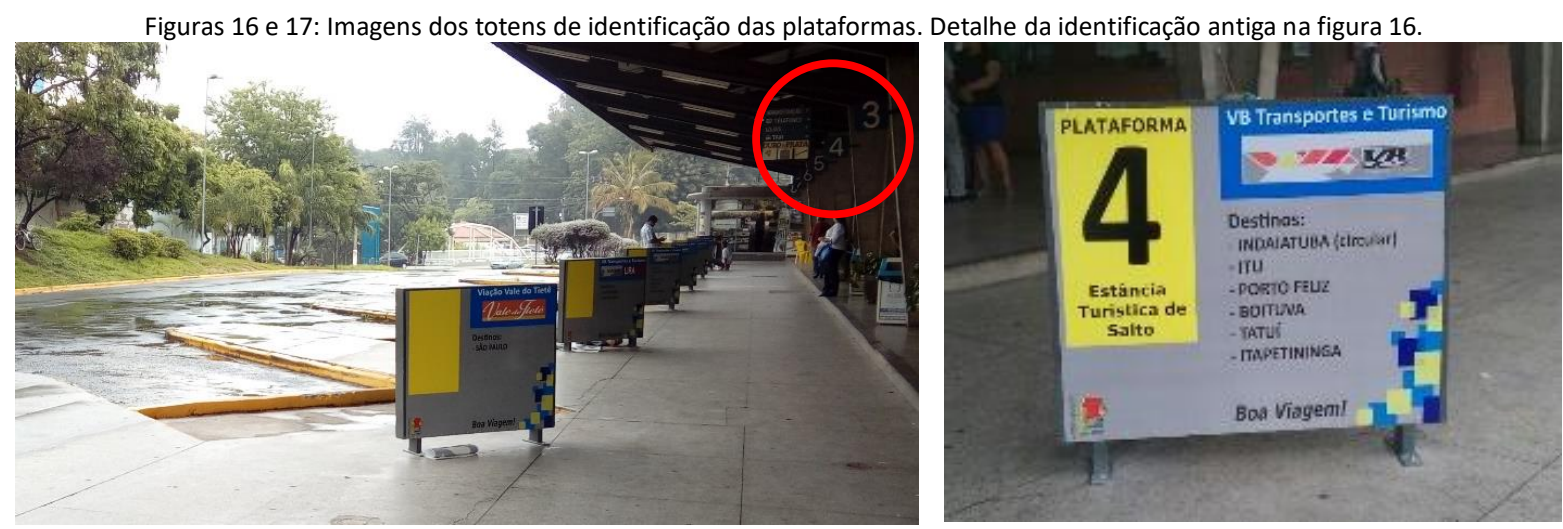

Fonte: foto da arquiteta, 20 de novembro de 2017. 


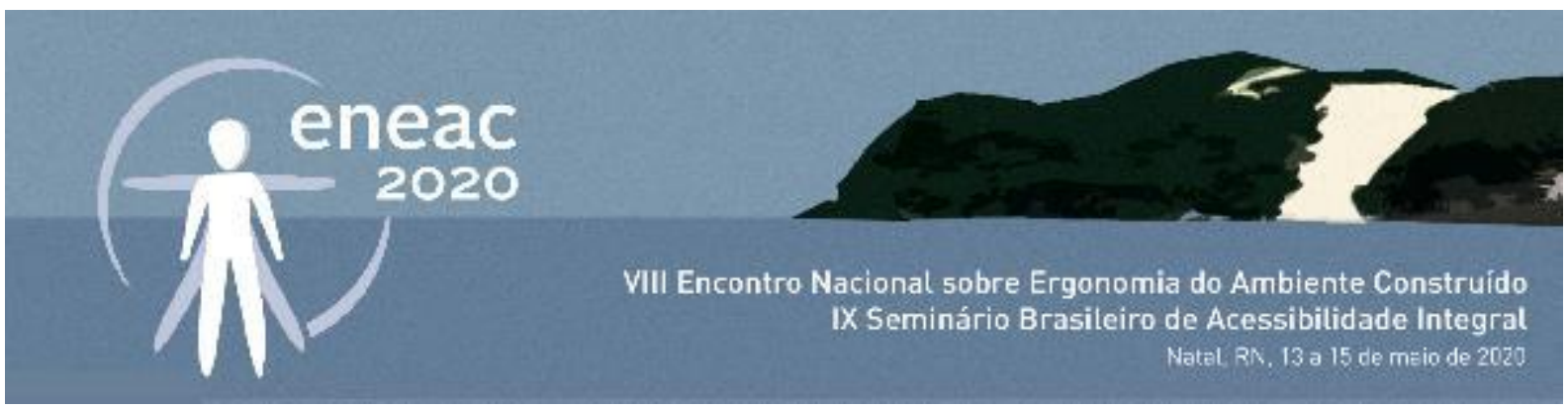

Infelizmente, em fevereiro de 2018, a Assistência Vicentina e a equipe técnica do projeto receberam críticas de três vereadores da cidade, através do jornal da cidade e redes sociais, afirmando que o Terminal não tinha acessibilidade, piso tátil e sanitário PNE, e que a Assistência Vicentina não tinha conhecimento técnico para administrar o Terminal, crítica essa que respondemos publicamente mostrando o Sanitário PNE em funcionamento já a mais de dois meses, e o projeto completo de acessibilidade a ser implantado. Importante dizer que não houve retratação dos vereadores, demonstrando como é difícil estabelecer um diálogo entre leigos e técnicos.

\subsection{Resultados da etapa 2 - grau improrrogável:}

Para a renovação do Auto de Vistoria do Corpo de Bombeiros foram realizadas as atualizações de segurança solicitadas. A rede elétrica foi totalmente renovada, foi instalado um sistema de alarme de incêndio e sinalização de emergência conforme os padrões atuais.

Atualmente estão sendo providenciadas as solicitações da última vistoria: corrimãos centrais nas escadas do lado direito do Terminal, e uma casa de gás externa para a lanchonete.

\subsection{Resultados previstos da etapa $\mathbf{3}$ - grau fundamental:}

Nessa etapa, a próxima a ser realizada, serão revitalizados os pisos de granilite, algumas peças serão lixadas e resinadas e outras, que estão quebradas, serão substituídas. Também serão executadas mais duas rampas de acessibilidade em locais mais visíveis e próximos aos guichês.

Figura 18: Detalhe do piso de granilite - peça superior recebera lixamento e resina, peça inferior será substituida.

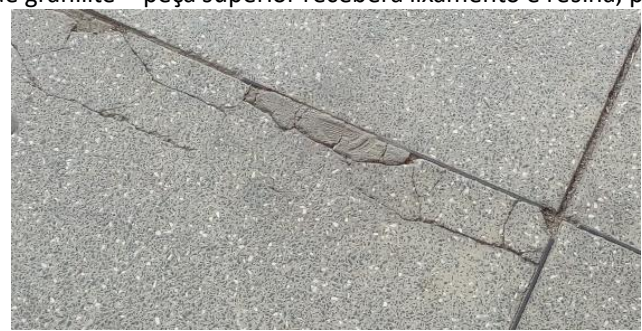

Fonte: foto da arquiteta, 2017

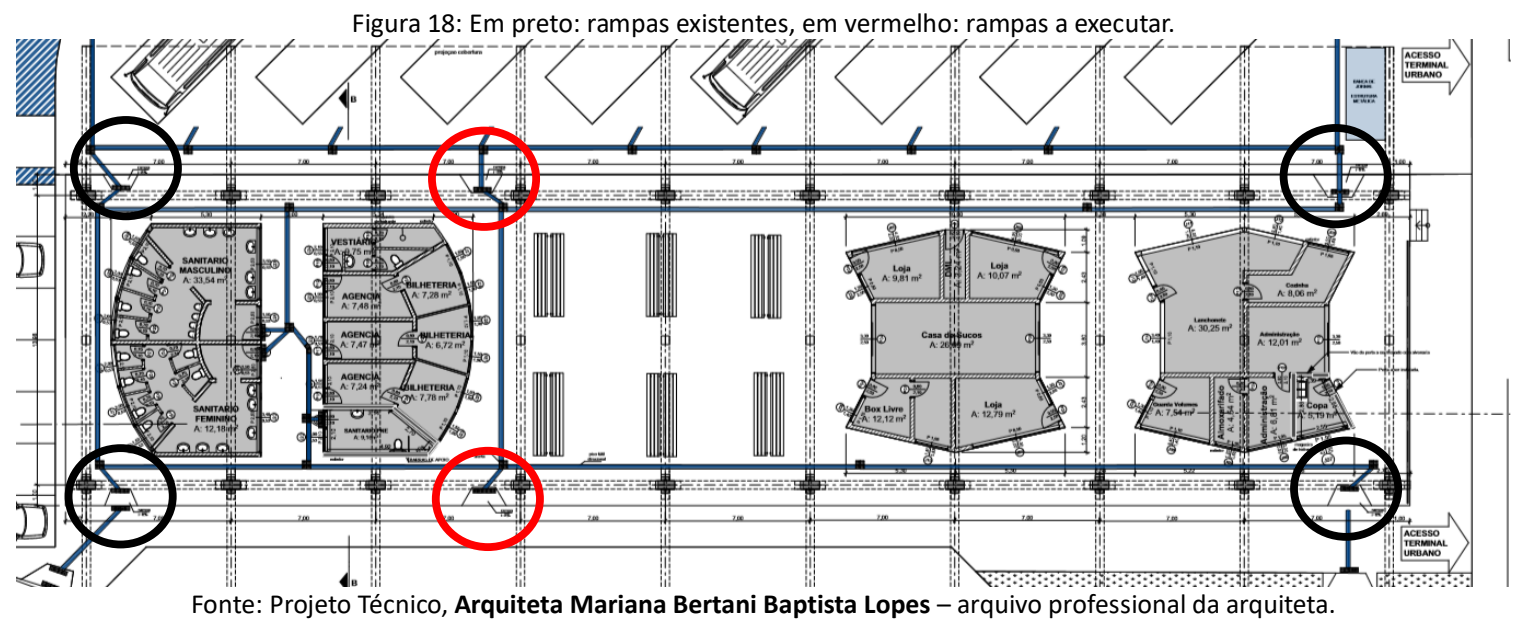

Em seguida serão instalados os pisos táteis. Conforme prevê o projeto de acessibilidade. 

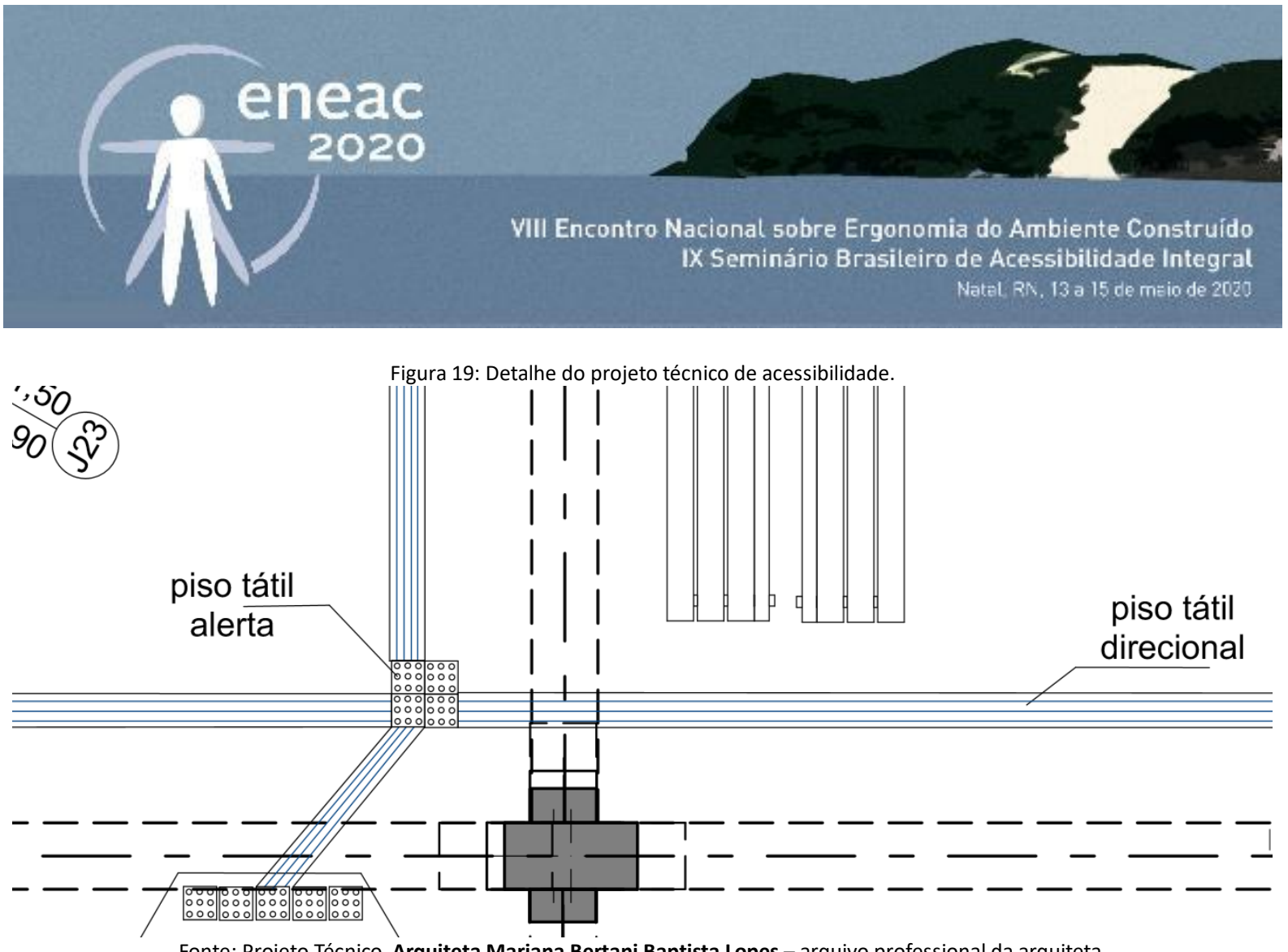

Fonte: Projeto Técnico, Arquiteta Mariana Bertani Baptista Lopes - arquivo professional da arquiteta.

\subsection{Resultados previstos da etapa 4 - finalização:}

A última etapa prevê a finalização da etapa visual, inserindo imagens da cidade e padronizando os letreiros dos boxes. Serão instalados também um mapa tátil do ambiente interno, e outro demonstrando a localização dos pontos turísticos da cidade.

Figuras 20 e 21: Referência do Mapa Tátil do Terminal Barra Funda em São Paulo, e estudo de ilustração para Mapa de Localização Turística, que também será estudado como Mapa Tátil.

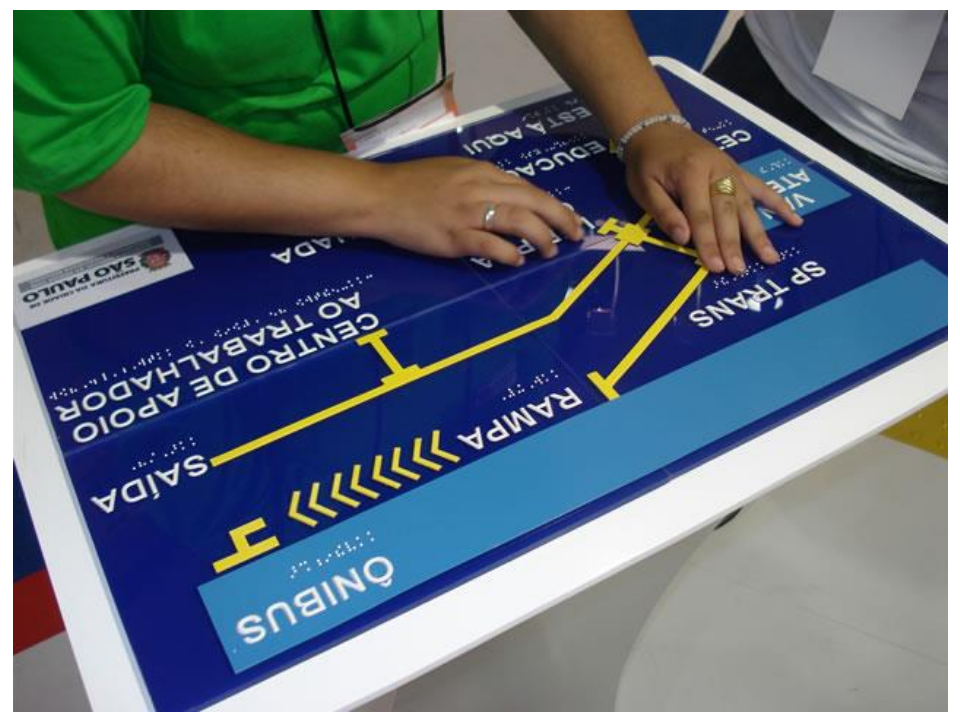

\section{COMPLEXO DA CACHOEIRA}
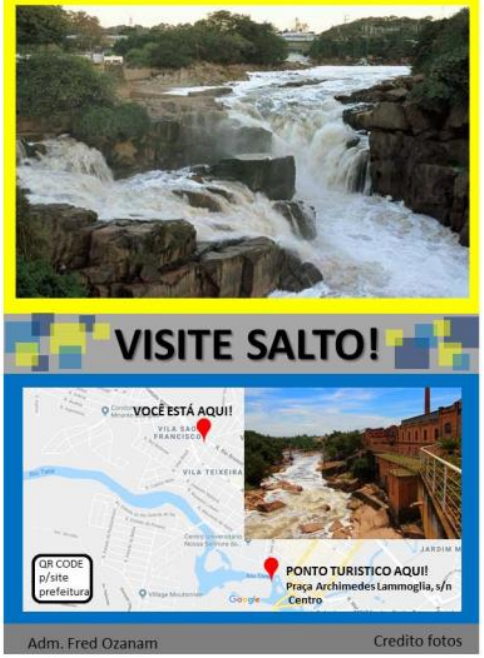

Fonte: Figura 20 - Divulgação da Prefeitura de São Paulo, 2017.

Figura 21 - Arquiteta Mariana Bertani Baptista Lopes - arquivo professional da arquiteta.

Além do tocante à acessibilidade, o projeto todo de revitalização englobou limpeza, pintura, jardinagem e propostas de layout com novos espaços. 

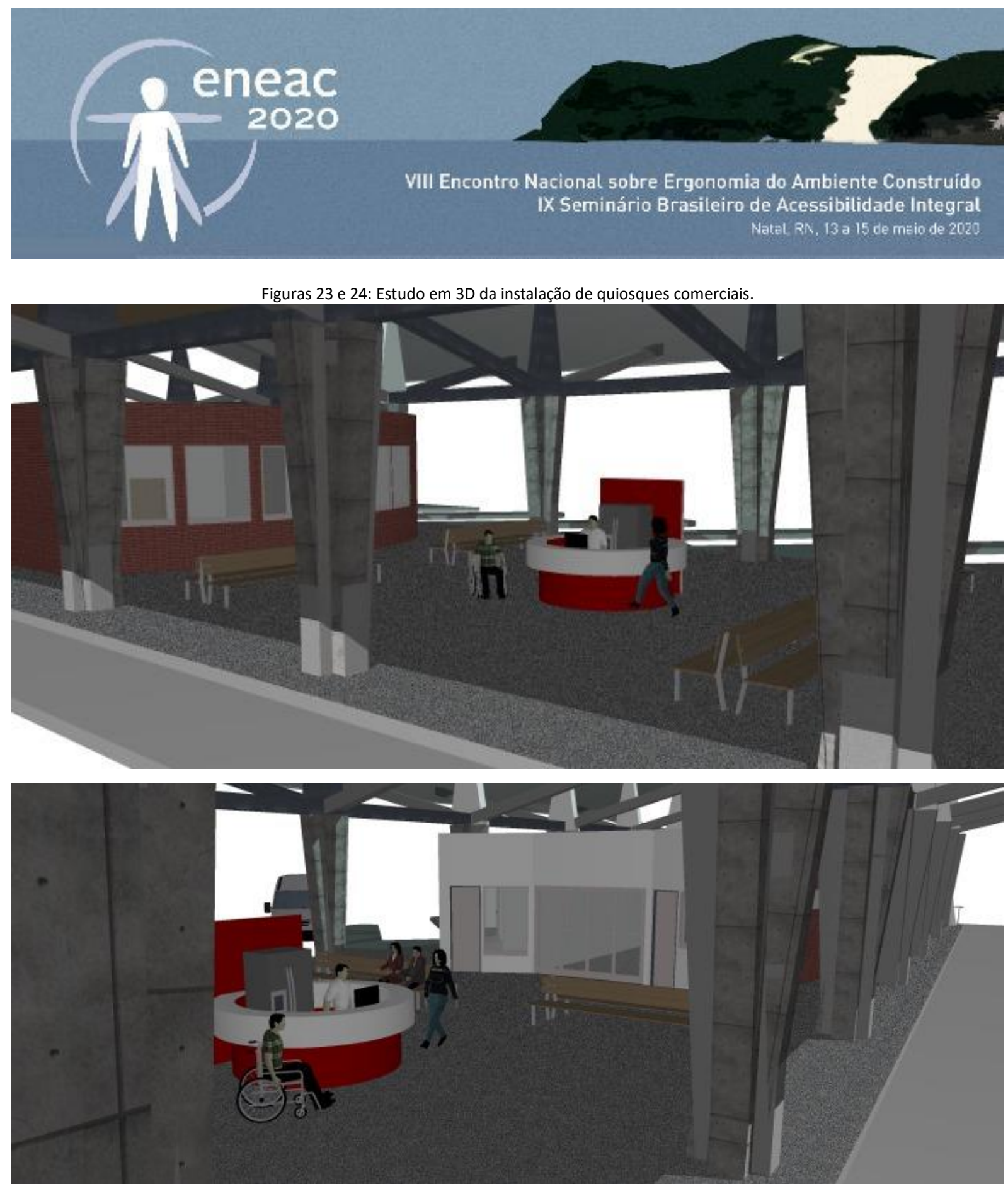

Fonte: Arquiteta Mariana Bertani Baptista Lopes - arquivo professional da arquiteta.

\section{CONCLUSÃO}

O Terminal Rodoviário de Salto é uma edificação de 32 anos, embora não seja tombada como patrimônio histórico todo o projeto de acessibilidade e revitalização teve como premissa principal interferir o mínimo em sua volumetria e características arquitetônicas originais.

Participar desse projeto tem permitido levar algumas discussões ao público, embora ainda de maneira informal através de redes sociais, e muitas vezes surgindo de forma acalorada, percebemos que aos poucos conseguimos esclarecer a necessidade das adequações, tanto as de acessibilidade quanto as de revitalização, e isso tem sido uma motivação a mais. 


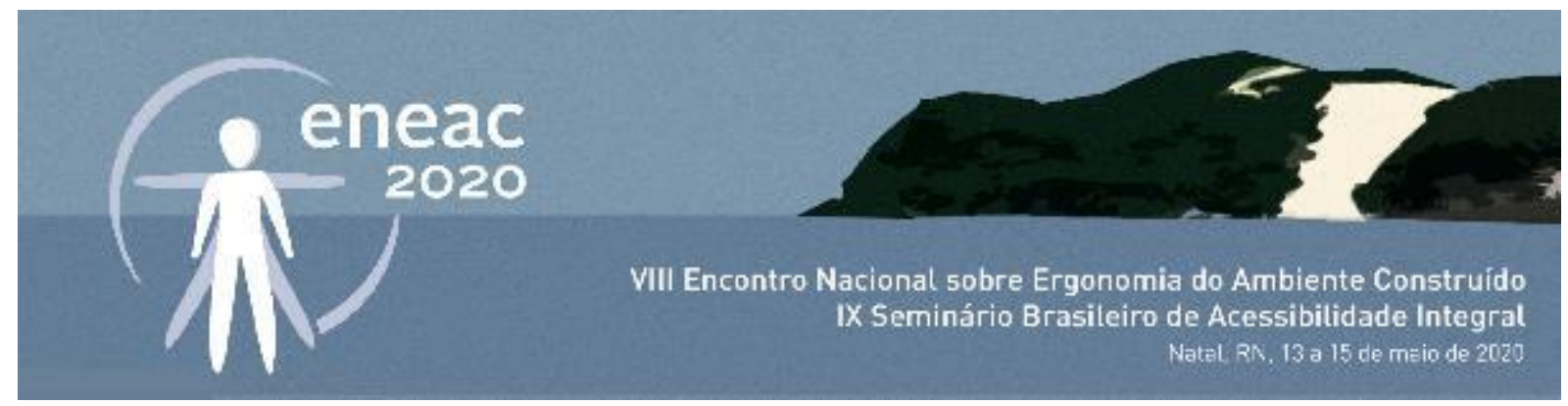

Pelo cronograma, a finalização de toda a execução do projeto está prevista para o segundo semestre de 2021, a tempo de apresentar o projeto finalizado no próximo ENEAC-SBAI.

\section{AGRADECIMENTOS}

Agradeço à Sociedade São Vicente de Paulo - Salto, na pessoa da Presidente Cícera Aparecida Gianotto Marzullo, pelo convite para participar desse trabalho, que carinhosamente chamamos de 'Desafio'. Agradeço aos funcionários do Lar Frederico Ozanam, sempre prontos a discutir e administrar as demandas do Terminal. Agradeço ao Mestre de Obras Wanderlando Sousa - Wando, pelo capricho em executar as obras, sempre com muito cuidado e responsabilidade.

Agradeço ao Secretário do Desenvolvimento Urbano da Estancia Turística de Salto, Arquiteto Sergio Baldi, por viabilizar a discussão do projeto de acessibilidade de maneira eficiente.

Agradeço à Prof. Dra. Núbia Bernardi, da Unicamp, pelos ensinamentos durante a iniciação científica, graduação e mestrado, que permitiram ser postos em prática neste projeto. Agradeço à Coordenadora Prof. Me. Renata Segalla, do Curso de Arquitetura e Urbanismo do Ceunsp por encorajar a participação no Congresso, e aos Professores Sandra Martins e Mateus Arruda, por compreender minha ausência durante a realização do Congresso.

Agradeço ao Comitê Organizador e ao Comitê Cientifico do XIII ENEAC - IX SBAI pela generosidade em considerar os efeitos das chuvas de verão na região Sudeste, pois mesmo os lugares não afetados diretamente por enchentes sofreram algum prejuízo nos serviços de internet. Agradeço ainda por considerar este artigo, mais prático que teórico, permitindo a esta autora participar com muita alegria da terceira edição seguida deste evento.

\section{REFERENCIAS}

CONSTITUIÇÃO BRASILEIRA: http://www.planalto.gov.br/ccivil 03/constituicao/constituicao.htm, acessado em janeiro de 2020.

FEIJÓ, A.R.A. Direitos Humanos e Proteção Jurídica da Pessoa Portadora de Deficiência: Normas Constitucionais de Acesso e Efetivação da Cidadania à Luz da Constituição Federal de 1988. Brasília: Ministério da Justiça, Secretaria de Estado dos Direitos Humanos, $184 \mathrm{pp}$.

Lei Federal 10.098 de 2000. http://www.planalto.gov.br/ccivil 03/leis/L10098.htm, acessado em janeiro de 2020.

Lei Municipal 3.695 de 2017 http://rodoviariadesalto.com.br/rodoviaria-lei-concessao/, acessado em janeiro de 2020.

NBR 9050/2015: http://www.abntcatalogo.com.br, acessado em janeiro de 2020. 